\title{
Penambahan Madu sebagai Pemanis Alami untuk Meningkatkan Nilai Organoleptik, Overrun dan Daya Leleh pada Es Krim
}

\author{
Qadriansyah A. Razak $^{1}$, Rajmi Faridah ${ }^{1 *}$, Bahri Syamsuryadi ${ }^{1}$ \\ ${ }^{1}$ Program Studi Peternakan, Fakultas Sains dan Teknologi, Universitas Muhammadiyah Sinjai \\ . Jl. Teuku Umar No. 8, Biringere, Sinjai Utara 92611, Sulawesi Selatan, Indonesia \\ *rajmifaridah@gmail.com
}

\section{INFORMASI ARTIKELL}

Diterima 28 January

2021

Hasil revisi diterima 24

Juni 2021

Diterbitkan 24 Juni 2021

Publish online 24 Juni

2021

Kata-kata kunci:

Es krim;

Madu;

Organoleptik;

Overrun;

Daya leleh;

\section{ARTICLE INFO}

Article history

Received 28 January

2021

Received in revised from 24 June 2021

Accepted 24 June 2021

Available online 24 June 2021

Key words:

Ice cream;

Honey;

Organoleptic;

Melting ability.

\section{ABSTRAK}

Penelitian ini bertujuan untuk mengetahui pengaruh penambahan madu terhadap nilai organoleptik, overrun dan daya leleh pada es krim. Penelitian ini dilaksanakan pada bulan Mei sampai Juni. Parameter yang dikur dalam penelitian ini adalah karakteristik organoleptik, overrun, dan daya leleh. Rancangan yang digunakan adalah Rancangan Acak Lengkap (RAL) dengan 4 perlakuan dan 3 kali ulangan $(0 \%, 10 \%, 20 \%, 30 \%)$. Proses pembuatan es krim sebagai berikut : semua bahan ditimbang kemudian dicampurkan dan dipasteurisasikan pada suhu 30\% selama 15 menit lalu diaging selama 24 jam pada suhu $4^{\mathrm{O}} \mathrm{C}$ setelah itu dimikser selama 30 menit kemudian dibekukan pada suhu $-25^{\circ} \mathrm{C}$ sampai $30{ }^{\circ} \mathrm{C}$. Hasil penelitian menunjukkan bahwa penambahan presentase madu pada es krim tidak memberikan perbedaan terhadap karakteristik warna aroma, rasa tekstur tetapi memberikan perbedaan terhadap overrun dan daya leleh. 


\section{PENDAHULUAN}

Es krim adalah jenis makanan semi padat yang dibuat dengan cara pembekuan tepung es krim atau campuran susu, lemak hewani maupun nabati, gula dan dengan atau tanpa bahan makanan lain yang di izinkan (Badan Standardisasi Nasional, 1995). Es krim yang tergolong baik, tentunya memiliki tekstur dan penampakan yang halus dengan cita rasa yang enak dimulut. Es krim yang tergolong sedang memiliki tekstur dan penampakan yang agak kasar karena mengandung kristal es yang cukup banyak. Seiring perkembangan zaman, es krim kini dibuat dalam berbagai variasi untuk menarik minat pembeli sehingga harus diperhatikan kualitas dan mutunya.

Bahan pemanis yang sering digunakan adalah gula pasir. Penggunaan gula terlalu banyak dalam makanan dapat menimbulkan gula darah serta menimbulkan obesitas. Untuk menghindari hal tersebut, gula dapat diganti dengan pemanis alami seperti madu (Jarvis. 2002). Penambahan madu diharapkan dapat meningkatkan nilai Overrun es krim, nilai Organoleptik dan daya leleh.

Kandungan dalam madu memiliki manfaat yang baik untuk tubuh diantaranya terdapat vitamin A, B1, B2, B3, B5, B6, C, D, $\mathrm{E}, \mathrm{K}$, beta karoten, flavanoid, asam glutamat, asam fenolik, asam asetat, dan asam nikotinat. madu juga memiliki kandungan mineral dan garam atau zat lain seperti zat lain seperti zat besi, sulfur, magnesium, kalsium, kalium, khlor, natrium, fosfor, sodium, serta antibiotika dan enzim pencernaan. Rata-rata komposisi madu berupa 17,17.11. \% air ; 82,4 $\%$ karbohidrat ; 0,5\% protein, asam amino, vitamin dan mineral. Madu merupakan salah satu karbohidrat dengan indeks glikemik yang rendah (Bogdanov et al., 2008).

Berdasarkan hal tersebut perlu dilakukan penelitian mengenai penanbahan madu ke dalam es krim, sehingga diharapkan akan meningkatkan nilai Organoleptik dan nilai Overrun pada es krim. Hal inilah yang melatar belakangi penulis mengangkat judul penelitian ini. Tujuan penelitian ini adalah untuk mengetahui pengaruh penambahan madu terhadap nilai organoleptik, overrun dan daya leleh pada es krim.

\section{METODE PENELITIAN}

\section{Rancangan Penelitian}

Metode penelitian ini adalah penelitian eksperimen dengan menggunakan Rancangan Acak Lengkap (RAL) dengan 4 taraf perlakuan Organoleptik dan Overrun, 3 ulangan untuk overrun dan daya leleh dan 20 panelis sebagai ulangan untuk uji Organoleptik. Perlakuan adalah perbandingan penambahan madu yang terdiri dari 4 taraf perlakuan yakni $0 \%, 10 \%, 20 \%$ dan $30 \%$. Rincian perlakuan adalah sebagai berikut:

P0 : Penambahan madu 0\%

P1 : Penambahan madu $10 \%$

P2 : Penambahan madu $20 \%$

P3 : Penambahan madu 30\%

\section{Prosedur Penelitian}

Pencampuran bahan yaitu susu, wippy cream, maizena, dan kuning telur. Pasteurisasi pada suhu $30^{\circ} \mathrm{C}$ selama 15 menit. Penambahan madu (0\%, 10\%, 20\% dan 30\%) ke dalam adonan sesuai dengan perlakuan.selanjutnya didinginkan pada suhu $4^{\circ} \mathrm{C}$ selama 24 jam. Adonan dimixer selama 25 menit dibekukan (aging) pada suhu $-25^{\circ} \mathrm{C}$ ke dalam freezer. Kemudian dikemas dan diuji Organoleptik, overrun dan daya leleh.

\section{Parameter Penelitian}

\section{Uji Overrun}

Uji overrun dilakukan dengan cara perhitungan selisih berat antara adonan dengan es krim setelah dilakukan pengocokan. Sampel berupa adonan es krim dimasukkan kedalam erlenmeyer $100 \mathrm{ml}$ lalu ditimbang. Lalu mencatat berat adonan es krim. Langkah berikutnya yaitu penimbangan 
es krim setelah dilakukan pengocokan, es krim dimasukkan kedalam erlenmeyer 100 ml lalu ditimbang menggunakan timbangan analitik, dicatat hasil penimbangan (Zahro dan Nisa, 2015). Dilakukan perhitungan dengan rumus:

$$
=\frac{\text { berat adonan }- \text { berat es krim }}{\text { berat adonan }} X 100
$$

\section{Uji Organoleptik}

Uji sifat organoleptik merupakan salah satu uji yang dilakukan untuk mengetahui daya terima masyarakat terhadap pengembangan produk. Uji hedonik dengan atribut warna, aroma, rasa, dan tekstur menggunakan 20 orang panelis semi terlatih. Uji hedonik digunakan untuk mengetahui urutan tingkat kesukaan panelis terhadap produk.

Skala numerik uji warna yaitu sangat tidak kuning (1), tidak kuning (2), cukup kuning (3), kuning (4) dan sangat kuning (5). Skala numerik uji aroma yaitu sangat tidak beraroma susu (1), tidak beraroma susu (2), cukup beraroma susu (3), bearoma susu (4), dan sangat beraroma susu (5). Skala numerik uji rasa yaitu sangat tidak manis (1), tidak manis (2), cukup manis (3), manis (4), dan sangat manis (5). Skala numerik uji tekstur yaitu sangat tidak halus (1), tidak halus (2), cukup halus (3), halus (4) dan sangat halus (5). Skala numerik uji hedonik yaitu sangat tidak suka (1), tidak suka (2), cukup suka (3), suka (4), dan sangat suka (5).

\section{Uji Daya Leleh}

Uji pelelehan es krim dilakukan dengan metode dari modifikasi (Malaka, 2014) : Es krim yang telah dikemas dalam kemasan es krim $100 \mathrm{ml}$ yang telah dibekukan pada suhu $-24^{\circ} \mathrm{C}$ selama 24 jam, kemudian dikeluarkan pada suhu kamar, dan diukur cairan yang meleleh setiap interval 10 menit sampai semua es krim meleleh.

\section{Analisis Data}

Data hasil penelitian dianalisis dengan Anova pada taraf keyakinan 95\%. Apabila hasil analisis data terdapat beda nyata maka dilanjutkan dengan Uji Duncan untuk mengetahui perbedaan perlakuan (Gomez dan Gomez, 1983).

\section{HASIL DAN PEMBAHASAN}

\section{Warna Es Krim}

Madu mengandung berbagai jenis komponen gizi yang sangat bemanfaat bagi manusia, yaitu karbohidrat, asam amino, mineral, enzim, vitamin, air dan zat-zat organik lainnya. Madu sebagian besar mengandung karbohidrat berupa glukosa dan fruktosa yang sudah jelas berbeda dengan gula atau gula aren. Pencampuran susu dengan madu tidak berubah warna dapat dilihat pada gambar 1 .

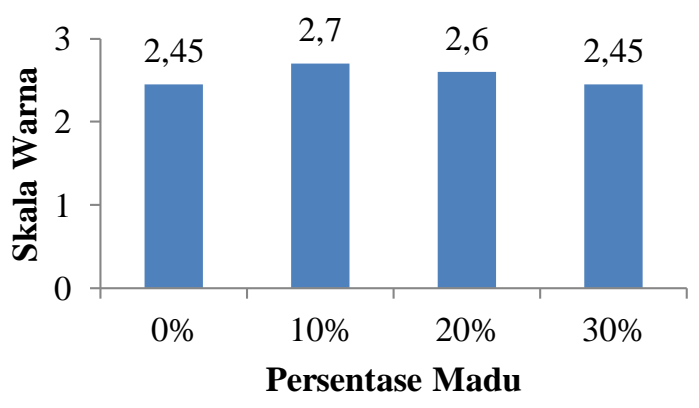

Gambar 1. Warna es krim dengan penambahan madu

Hasíl analisis ragam menunjukkan bahwa penambahan madu tidak berpengaruh $(\mathrm{P}>0,05)$, terhadap persentase warna susu yang ditambahkan dengan madu tidak berubah. Rata-rata yang dipilih oleh panlies yaitu tidak kuning. Hal ini di sebabkan karena penambahan madu di campur ke dalam susu mengandung fruktosa, glukosa dan sukrosa yang mudah larut dalam air saat pasteurisasi. Madu memiliki kandungan Maillard dan peptid yaitu zat warna pada madu yang dapat mempengaruhi warna pada susu. 


\section{Aroma Es Krim}

Kandungan senyawa pada suatu bahan terlarut dalam air dan lemak mampu menghasilkan aroma. Indera penciuman berfungsi mendeteksi aroma yang menguap bersama senyawa di udara. Aroma susu umumnya mencirikan aroma khas yang dapat berubah bila terkena senyawa atau benda tertentu (Nurwantoro, 2009). Hasil organoleptik mencakup aroma pada es krim dengan penambahan madu disajikan pada Gambar 2.

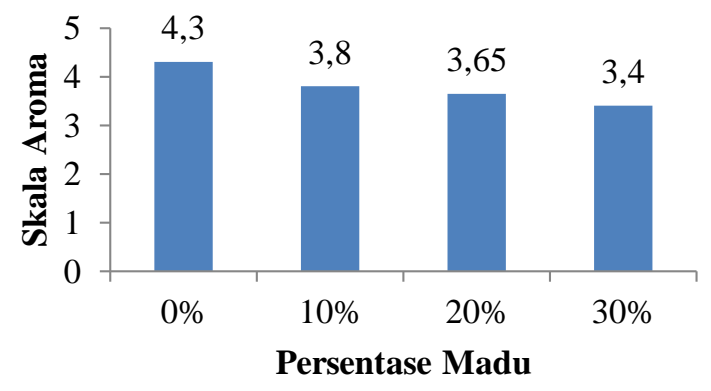

Gambar 2. Aroma es krim dengan penambahan madu

Hasil analisis ragam menunjukkan bahwa penambahan madu tidak berpengaruh ( $P>0,05)$, terhadap aroma susu pada es krim. Berdasarkan gambar 2 penambahan madu dalam susu tidak mempengaruhi aroma susu karena madu memiliki kandungan antibotika dan antibakteri yang mampu mempertahankan aroma susu pada es krim, hal ini dipengaruhi oleh sifat lemak susu yang mudah menyerap bau disekitarnya. Nurwanto (2009) menyatakan bahwa bau susu umumnya sedap, namun juga sangat mudah berubah bila lerkena benda-benda tertentu. Susu terbagi menjadi 2 bagian besar yaitu $87.25 \%$ air dan $12,7 \%$ zat padat zat padat tersebut terbagi menjadi $3,08 \%$ lemak, $3,5 \%$ protein, $4,8 \%$ laktosa, $0,65 \%$ mineral. Zat-zat padat tersebut memberi aroma khas pada susu.

\section{Uji Rasa Es Krim}

Hasil penelitian memperlihatkan nilai skor rasa es krim dengan penambahan madu dengan konsetrasi yang berbeda berkisar antara 4,4 - 5,02. Hasil uji organoleptik rasa es krim dengan penambahan madu, disajikan pada Gambar 3.

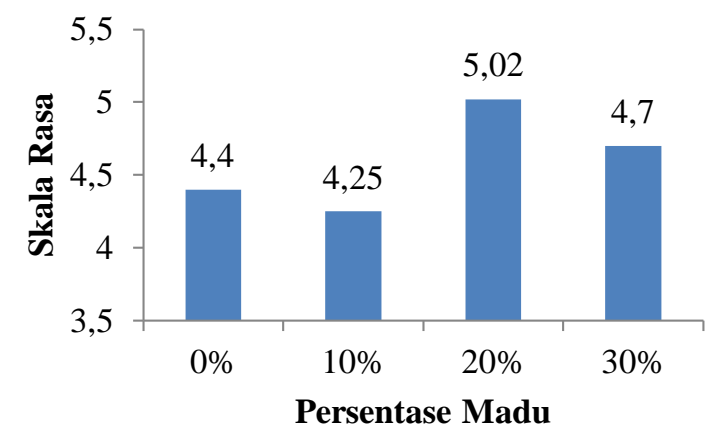

Gambar 3. Rasa es krim dengan penambahan madu

Gambar 3 menunjukan bahwa nilai uji rasa tidak berpengaruh $(\mathrm{P}>0,05)$. Nilai ratarata dengan penambahan madu yaitu $10 \%$ dengan nilai 4,25 dengan rasa manis dan $20 \%$ dengan nilai rata-rata 5.05 dengan rasa yang sangat manis dan $0 \%$ dengan nilai rata-rata 4.80 tanpa penambahan madu dengan rasa manis. Sedangkan persentase $30 \%$ dengan nilai rata-rata 4.70 dengan rasa manis. Sedikit banyaknya madu atau gula yang ditambahkan kedalam es krim, akan mempengaruhi rasa pada es krim.

Bahan pemanis yang biasa digunakan adalah sukrosa. Bahan sukrosa yang paling banyak digunakan adalah gula pasir. Selain gula yang ditambahkan sebagai bahan pemanis, gula pada es krim juga termasuk laktosa yang berasal dari susu (Padaga dan Sawitri, 2005).

\section{Uji Tekstur Es Krim}

Hasil penelitian memperlihatkan nilai skor tekstur es krim dengan penambahan madu dengan konsentrasi yang berbeda antara 
2,8 - 4,85. Data hasil penelitian dapat disajikan pada Gambar 4.

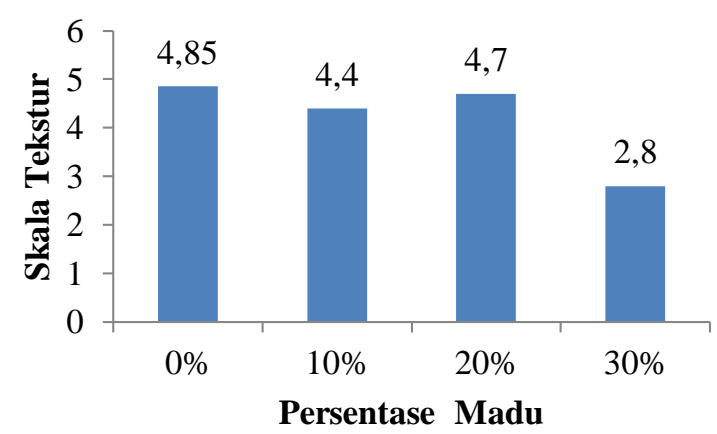

Gambar 4. Tekstur es krim dengan penambahan madu

Berdasarkan gambar 4 dari nilai uji tekstur tidak berpengaruh $\mathrm{P}(\mathrm{P}>0,05)$, dilihat dari gambar 4, 0\% tanpa penambahan madu menjadikan tekstur yang sangat halus sedangkan persentase dengan penambahan madu $10 \%$ - 30\% mergalami penurunan terhadap tekstur es krim, hal ini disebabkan karena madu tidak mudah larut dalam air dan tingginya kandungan zat madu sehingga tekstur dallam es krim menjadi kasar, (Rahmani, 2004).

\section{Uji Kesukaan Es Krim}

Hasil penelitian memperhatkan nilai skor uji hedonik es krim dengan penambahan madu dengan konsentrasi yang berbeda berkisar antara 3,3 - 48. Hasil uji organoleptik kesukaan es krim madu disajikan pada Gambar 5.

Hasil analisis ragam menunjukkan bahwa penambahan madu tidak berpengaruh ( $>>0,05)$. terhadap tekstur es krim, hal di sebabkan karena tingginya gula dan kandungan zat madu dapat menimbulkan es krim menjadi sangat manis dan tidak disukai oleh panelis. Aktivitas enzim diastase dan kadar sukrosa menyatakan bahwa kadar sukrosa empat dari lima merk madu melebihi kadar maksimal sukrosa menurut syarat mutu madu (Badan Standardisasi Nasional, 2004).

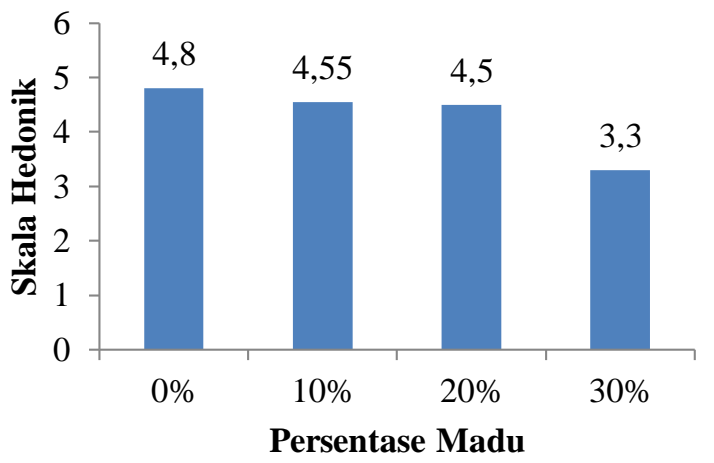

Gambar 5. Hedonik es krim dengan penambahan madu

Uji organoleptik keseluruhan digunakan dalam uji hedonik untuk mengetahui dan mengukur tingkat kesukaan panelis terhadap keseluruhan atribut ada pada produk atau makanan. Hal ini dilakukan karena uji panelis terhadap parameter lain seperti rasa, aroma, warna, dan tekstur menghasilkan nilai berbeda-beda (Gustiar, 2009). Uji tingkat kesukaan terhadap panelis dilakukan untuk mendapatkan formulasi produk atau makanan yang terbaik.

\section{Daya Leleh}

Daya leleh adalah waktu yang dibutuhkan es krim untuk meleleh seluruhnya pada suhu ruang. Kecepatan pelelehan ini sebagai salah satu parameter untuk mengetahui kualitas es krim (Syafarini dan Isnaini, 2009). Hasil penelitian terhadap rata-rata daya leleh (menit) es krim dengan penambahan madu sebagai pemanis alami disajikan pada Gambar 6.

Berdasarkan hasil Gambar 6 (Lampiran) menunjukkan hasil uji daya leleh bahwa penambahan madu menghasilkan perbedaan sangat nyata $(\mathrm{P}<0.01)$, terhadap kecepatan daya leleh es krim. Penambahan madu pada es krim dapat memperlambat daya leleh dikarenakan madu dak mudah larut dalam air sehingga mempengarahui daya leleh es krim. Hasil lanjut Duncan persentase 0\% tanpa penambahan madu dengan nilai 10.30 
sedangkan persentase 10\%-30\% dengan penambahan madu mengalami peningkatan terhadap daya leleh es krim. Pada gambar 6, kisaran pelelehan yang baik adalah 10-30\% dengan waktu pelelehan 14:20 menit, 17:16 manit dan 23:40 menit.

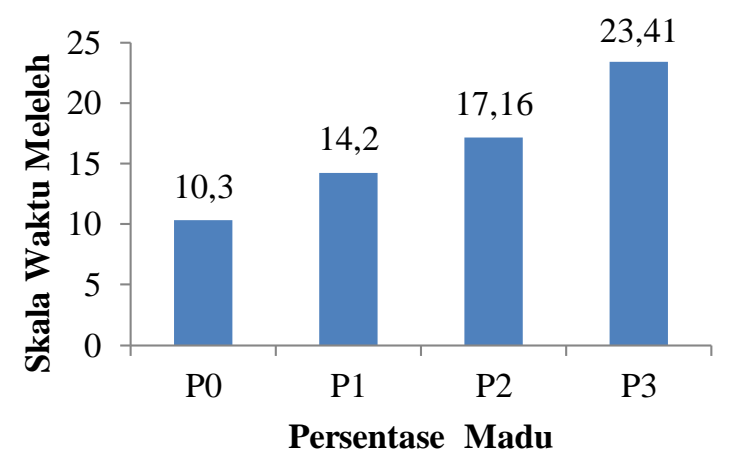

Gambar 6. Daya leleh es krim dengan penambahan madu

Menurut Badan Standardisasi Nasional (1995), bahwa kisaran pelelehan yang baik pada es krim adalah 15-25 menit. Es krim dengan penambahan madu pada setiap perlakuan tergolong baik. Es krim yang mudah meleleh ataupun terlalu keras tidak disukai oleh konsumen Daya terima konsumen pada es krim dengan menilai es krim yang lembut dan tidak mudah meleleh pada suhu ruang $\left( \pm 27^{\circ} \mathrm{C}\right)$. Kandungan serat yang tinggi pada es krim dengan pe nambahan madu mampu meningkat kan total padatan es krim.

\section{Uji Overrun}

Overrun adalah jumlah pening katan volume yang disebabkan karena masuknya udara ke dalam campuran es krim. Gelembung-gelembung udara yang terbentuk keberadaannya dapat dipertahankan karena diselubungi oleh lapisan-lapisan globula lemak dalam sistem emulsi. Tanpa adanya overrun, maka es krim akan berbentuk gumpa lan massa yang berat dan tidak mena rik untuk dimakan. Overrun dapat di hasilkan karena pengocokan yang dila kukan ketika proses pembekuan berlangsung. Karena pengocokan udara dapat masuk dalam campuran es krim sehingga meningkatkan volume adonan es krim Oksilia (2012). Hasil penelitian terhadap nilai rata-rata Over run dapat disajikan pada gambar 7.

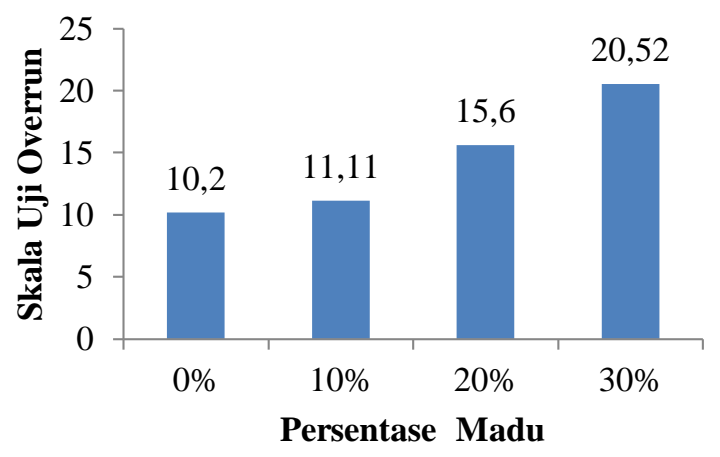

Gambar 7. Nilai overrun es krim dengan penambahan madu

Berdasarkan hasil gambar 7 me nunjukkan hasil uji overrun dengan penambahan madu, berbeda sangat nyata $(\mathrm{P}<0.01)$, terhadap bobot es krim. Hasil uji lanjut Duncan persentase 0\% - 30\% memiliki masing masing perbedaan terhadap bobot es krim, ini timbul karena semakin banyak persentase madu yang digunakan akan semakin besar bobot es krim yang dihasilkan.

\section{KESIMPULAN}

Peningkatan persentase madu pada es krim tidak memberikan perbedaan pada karakteristik organoleptik meliputi rasa, aroma, warna, dan tekstur tetapi berbeda terhadap nilai overrun dan daya leleh. Presentase madu yang baik digunakan pada es krim adalah persentase $20 \%$.

\section{DAFTAR PUSTAKA}

Badan Standardisasi Nasional. (2004). Standar Nasional Indonesia: Madu (SNI 01-3454-2004). Jakarta: BSN. 
Badan Standardisasi Nasional. (1995). Tentang Mutu Es Krim. Makanan dan Minuman. Jakarta: BSN.

Bogdanov, S., Jurendic, T., Sieber, R., \& Galman, P. (2008). Honey for nutrition and health: a review. Journal of the American Collage of Nutrition, 27(6), 677-689.

Gustiar, H. (2009). Sifat Fisik Kimia dan Indeks Glikemi Produk Cookies Berbahan Baku Pati garut (Marantaarundinacea) Termodifikasi. Tesis. Bogor: IPB.

Gomez, K.A., \& Gomez, A.A. (1983). Statistical Procedures for Agricultural Research. Second Ed. New York: John Wiley and Sons.

Jarvis, D.C. (2002). Khasiat Madu Hidup Sehat Ala Rasul. Yogyakarta: Javaliteria.

Malaka, R. (2014). Teknologi Aplikatif Pengolahan Susu. Surabaya: Brilian Internasional.

Nurwantoro. (2009). Bahan Ajar Dasar Teknologi Hasil Ternak. Semarang:
Fakultas Peternakan Univer sitas Diponegoro.

Oksilia, Syafutri, M.I., \& Lidiasari, E. (2012) Karakteristik es krim hasil modifkasi dengan formulasi bubur timun suri dan kedelai. Jurnal: Teknologi dan Industri Pangan, 23(1), 17-22.

Padaga, M., \& Sawitri, M.E. (2005). Es krim yang sehat. Trubus. Surabaya: Agrisana.

Rahmani, M.F. (2004). Keakuratan Metode Uji Larut Untuk Keaslian Madu (Studi Kasus di Kota Bogor). Skripsi. Bogor: Fakultas Peternakan IPB.

Syafarini dan Isnaini. (2009). Karakteristik Produk Tepung Es Krim de ngan Penambahan Hidrokoloid Karaginan dan Alginat. Skripsi. Bogor: Fakultas Perikanan dan Ilmu Kelautan IPB.

Zahro, C., \& Nisa, F.C. (2015). Pengaruh penambahan sari anggur (Vitis vinifera L.) dan penstabil terhadap karakteristik fisk kimia dan organoleptik es krim. Jurnal Pangan dan Agroindustri, 3(4), 1481-1491. 